\title{
Comparison of Road Traffic Noise near High, Medium and Low Density Residential Areas in Nibong Tebal and Juru, Penang
}

\author{
Herni Halim ${ }^{1, *}$, Nur Hanani Farhah Mohd Hilmi' ${ }^{1}$, Mohamad Firdaus Mahamad \\ Yusob $^{2}$, Nur Fatin Najiyah Hamid ${ }^{1}$, Nur Atiqah Mohamad Nor ${ }^{1}$, Nur Sabahiah \\ Abdul Sukor ${ }^{1}$, Noorhazlinda Abdul Rahman ${ }^{1}$, Zaiton Haron ${ }^{3}$, Faridah Wahab ${ }^{4}$
}

${ }^{1}$ School of Civil Engineering, Engineering Campus,

Universiti Sains Malaysia, 14300 Pulau Pinang, MALAYSIA

${ }^{2}$ School of Electrical and Electronic Engineering, Engineering Campus,

Universiti Sains Malaysia, 14300 Pulau Pinang, MALAYSIA

${ }^{3}$ Department of Structure and Materials, Faculty of Civil Engineering,

Universiti Teknologi Malaysia, 81310 Johor, MALAYSIA

${ }^{4}$ School of Environmental Engineering,

Universiti Malaysa Perlis, 02600 Perlis, MALAYSIA

*Corresponding Author

DOI: https://doi.org/10.30880/ijie.2019.11.01.010

Received 12 June 2018; Accepted 17 September 2018; Available online 05 May 2019

\begin{abstract}
Nowadays, environmental noise pollution is ranked second among other environmental pollutions in terms of public health impacts due to rapid urbanization and growing traffic especially road traffic. The aim of this study is to assess traffic noise levels between different types of residential areas in Nibong Tebal and Juru, Penang. This study compares road traffic noise levels in high density (Juru) and medium density (Nibong Tebal) residential areas in Penang. The noise levels measurements were carried out periodically in the morning (from 0700 to 1100), evening (from 1600 to 1900), and at night (from 2200 to 2300) for 15 minutes using sound level meter. The traffic characteristics were measured simultaneously during noise levels measurements. One-Way Analysis of Variance (ANOVA) was used to determine any significant differences between two or more noise levels measured at sites of the study. Independent samples t-test was used to compare independent groups (noise levels at two different study sites and areas). In the present study, $\mathrm{p}$ values of less than $5 \%(\mathrm{p}<0.005)$ were considered as statistically significant The results show that all of the noise levels measured in Juru and Nibong Tebal residential areas exceed the noise permissible limits stated in The Planning Guidelines For Environmental Noise Limits and Noise Control by low density residential areas with the permissible limits of $50 \mathrm{~dB}(\mathrm{~A})$ day time and $40 \mathrm{~dB}(\mathrm{~A})$ night time, suburban residential (medium density with the permissible limits of $55 \mathrm{~dB}(\mathrm{~A})$ day time and $45 \mathrm{~dB}(\mathrm{~A})$ night time) and urban residential (high density with the permissible limits of $60 \mathrm{~dB}(\mathrm{~A})$ day time and $55 \mathrm{~dB}(\mathrm{~A})$ night time). The equivalent continuous noise levels measured in Nibong Tebal residential areas are between $57.6-69 \mathrm{~dB}(\mathrm{~A})$ while in Juru residential areas, the noise levels measured are 66.65 to $70.7 \mathrm{~dB}(\mathrm{~A})$. All noise levels exceed the maximum permissible sound levels in both areas.
\end{abstract}

Keywords: Road traffic noise, residential area, vehicle speed, traffic characteristics 


\section{Introduction}

Road transportation plays a major role in the economic and social development of a country. In this era of global mass transportation and urbanization, traffic noise has become a critical issue [1]. With the increase in vehicle population, noise levels will increase [2]. Road traffic noise is one of the most widespread and growing environmental problems faced by the urban world. Many residents exposed to outdoor traffic noise consider it unacceptable for sound sleep and amenity [3]. Road-traffic noise is a widespread environmental nuisance which affects people in their residential dwellings and workplaces [4]. Residential exposure to noise pollution, particularly road traffic noise, is an important issue because people spend 10-15 hours per day at home than other places such as office and school [5].

In Malaysia, noise is the most frequently ignored type of pollution while water and air pollution are considered important to life because noise is merely an annoyance to some people only. Noise levels are considered extremely high if the noise exceeds $55 \mathrm{~dB}(\mathrm{~A})$ for day time and $45 \mathrm{~dB}(\mathrm{~A})$ for night time as recommended by the World Health Organization (WHO) [6]. In the European Union (EU), an estimate of more than $40 \%$ of the population are exposed to daytime traffic noise exceeding $55 \mathrm{~dB}(\mathrm{~A})$ in terms of equivalent continuous noise levels (LAeq), and 20\% are exposed to levels exceeding $65 \mathrm{~dB}(\mathrm{~A})$. At night, more than $30 \%$ are exposed to LAeq exceeding $55 \mathrm{~dB}(\mathrm{~A})$, which is not conducive to sleep [7]. Leq is defined as the constant average sound pressure level that hold the same value of acoustic energy as the discontinuous levels of noise in the period of time. In other words, noise fluctuate over a wide range with time. Leq is used as standard descriptor to determine noise especially at the highways, residential and commercial areas. Moreover, Leq is more functional and applicable and also internationally accepted for the traffic noise analyses [8]. Existing studies on road traffic noise in Malaysia have mostly measured in Kuala Lumpur Conurbation (Klang Valley) [9]-[12]. However less study is carried out in other states in Malaysia especially Penang. Penang is known as the second largest metropolitan and second growth center in Malaysia after Klang Valley [13]. This is due to Penang being an important hub for foreign direct investors. This study aims to determine the noise level of road traffic in high density and medium density population in selected residential areas in Juru and Nibong Tebal, respectively.

\section{Materials and Method}

The noise level monitoring was conducted using a sound level meter manufactured by Cirrus Research plc (Cirrus (UK) - CR:1710) periodically (morning 7.00 -11.00 am, evening $4.00-7.00 \mathrm{pm}$ and night $8.00-11.00 \mathrm{pm}$ ). In this study, noise for 15 minutes (the sound level meter recorded every one minute of noise level) was recorded. The justification of one minute data interval is that the noise levels are recorded as detail as possible to represent the noise levels at studied sites without missing any noise variation. Noise produced was not steady as noise level changed with time. Traffic noise level is influenced by traffic flow and speed. The time mean speed of traffic volume flow was obtained using Eq. (1).

$$
\bar{v}_{t}=\frac{1}{N} \sum_{n=1}^{N} v_{n}
$$

where $\bar{v} t$ is the time mean speed, $N$ is the number of speeds of the vehicles and $v n$ is the speed of the vehicles. In the analysis, LAeq data were used to describe the traffic noise in the studied sites. LAeq is a widely used noise descriptor and commonly adopted in many developed countries to explain noise level such as Denmark, United Kingdom, France and Sweden [14]-[16]. The main objective of noise measurement is to determine the noise levels at residential areas in Nibong Tebal and Juru, Penang.

\subsection{Study Areas}

This study presents the problem of noise pollution in terms of road traffic. This study was developed to collect environmental data in relation to road traffic noise by monitoring and analysis the measurements taken. This study was conducted at selected residential areas in Nibong Tebal and Juru, Penang. The selection of the studied sites is based on the different density of population in selected residential areas. Eight locations were chosen; six locations in Nibong Tebal areas with three studied sites represent low density population residential areas (Kampung Batu 2, Kampung Sungai Bakau and Kampung Simpang 3) and the other three sites represent medium density population residential areas (Taman Sri Acheh, Taman Pekaka and Taman Ilmu Indah). The map and coordinates of studied sites in Nibong Tebal is shown in Fig. 1 and Table 1, respectively. Another two residential areas in Juru represent high density residential areas (Taman Delima Jati and Flat Sri Delima) as shown in Fig. 2 and the coordinates of the studied sites are tabulated in Table 2. 


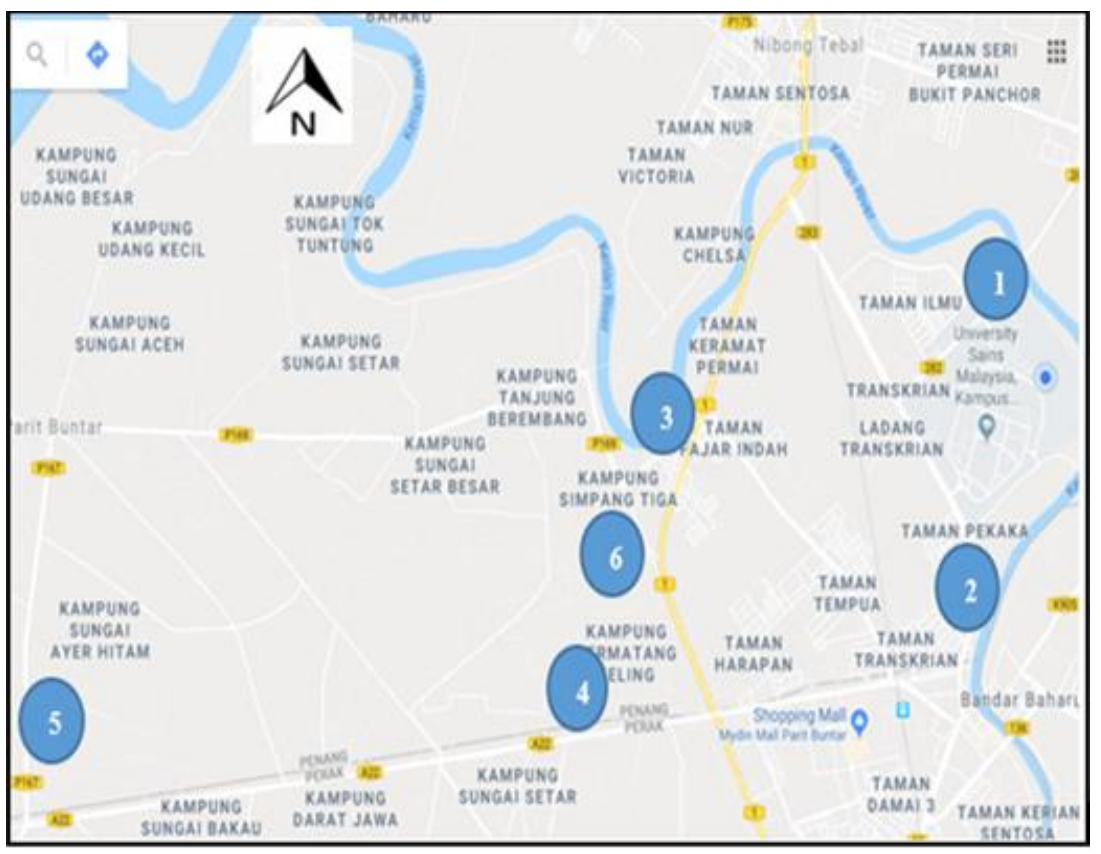

Fig. 1 - The locations of the studied sites in Nibong Tebal, Penang

Table 1 - Studied sites and coordinates in Nibong Tebal, Penang

\begin{tabular}{lc}
\hline \multicolumn{1}{c}{ Studied sites } & Coordinates \\
\hline 1.Taman Ilmu Indah & $5.164,100.500$ \\
2.Taman Pekaka & $5.138,100.492$ \\
3.Taman Sri Acheh & $5.144,100.469$ \\
4.Kampung Batu 2 & $5.129,100.467$ \\
5.Kampung Sungai Bakau & $5.126,100.419$ \\
6.Kampung Simpang Tiga & $5.141,100.465$ \\
\hline
\end{tabular}

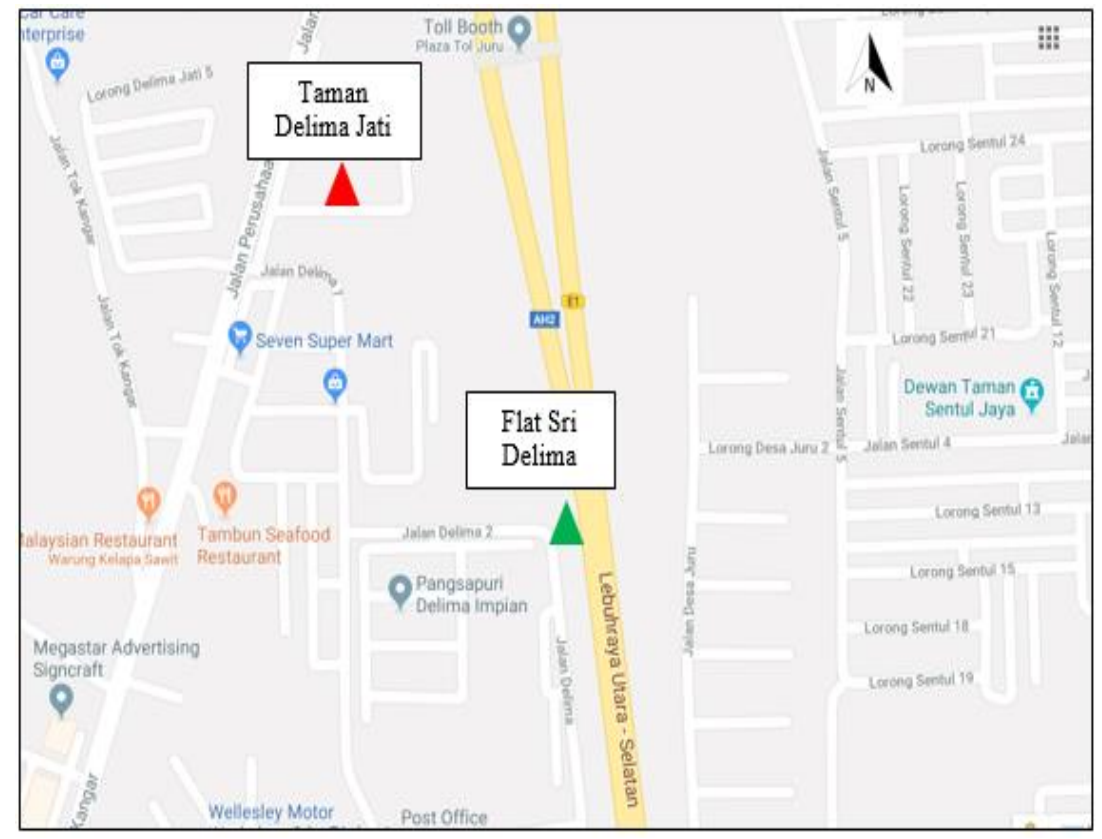

Fig. 2 - The locations of the study areas in Juru, Penang 
Table 2 - Studied sites and coordinates in Juru, Penang

\begin{tabular}{lc}
\hline \multicolumn{1}{c}{ Studied sites } & Coordinates \\
\hline 1.Taman Delima Jati & $5.322150,100.434142$ \\
2.Flat Sri Delima & $5.318015,100.436783$ \\
\hline
\end{tabular}

\subsection{Noise Levels Measurement}

The measurement of the noise and traffic data by using sound level meter was taken at 1 minutes interval for 15 minutes which are in the morning, afternoon and night so that variations of noise can be obtained. It was stated in the Planning Guidelines for environmental Noise Limits and Control [17]. The sound level meter was held $1.50 \mathrm{~m}$ above the ground surface on the highway shoulder at a distance of $5 \mathrm{~m}$ from the pavement edge [17]. A calibrator was used to routinely calibrate the sound level meter before and after the measurement session. The sound level meter was calibrated in $93.7 \mathrm{~dB}(\mathrm{~A})$.

The LAeq is the continuous equivalent sound level, defined as the single SPL that, if constant over the stated measurement period, would contain the same sound energy as the actual monitored sound that is fluctuating in level over the measurement period [18]. The LAeq must be qualified in terms of a time period to have meaning. Representation of the time period (in hours) is normally accomplished by placing it in parentheses, for example LAeq(1) refers to a 1-hour measurement and LAeq(24) refers to a 24-hour measurement. The LAeq is recognized as the descriptor of choice by many authorities in the world for traffic source in environmental noise assessments. LAeq, Aweighted sound pressure to the square of the standard reference sound pressure, the equivalent continuous level is given by Eq. (2) (theoretical equation) and Eq. (3) (practical formulation):

$$
\begin{aligned}
& L_{e q}=10 \log \left(\frac{1}{t_{2}-t_{1}} \int_{t_{1}}^{t_{2}} \frac{P_{A}^{2}(t)}{P_{0}^{2}}\right) \\
& L_{e q}=10 \log \left(\frac{1}{N} \sum_{i=1}^{i=n} 10 \frac{L_{A i}}{10}\right)
\end{aligned}
$$

where: $t_{1}, t_{2}=$ the start and finish times of the measurements, $P 0=$ the reference sound pressure, $2 \times 10^{-5} \mathrm{~N} / \mathrm{m}^{2}$, $\mathrm{Pa}(\mathrm{t})=$ the instantaneous $\mathrm{A}$-weighted sound pressure at time $\mathrm{t}, \mathrm{N}=$ the total number of sample during the period, $\mathrm{t}_{1}, \mathrm{t}_{2}$ and $\mathrm{L}_{\mathrm{Ai}}=$ the noise level in $\mathrm{dB}(\mathrm{A})$ of the $\mathrm{i}^{\text {th }}$ sample.

For the traffic composition, it has been categorized into four types of classes, which are Class 1-vehicles with 2 axles and 3 or 4 wheels excluding taxis, Class 2-vehicles with 2 axles and 5 or 6 wheels excluding buses, and Class 3vehicles with 3 or more axles [19]. In this study, cars were included in Class 1, small lorries in Class 2 and heavy vehicles in Class 3 and lastly motorcycle. The traffic measurement was recorded using manual count and using speed gun within 15 minutes observation. The manual count was used to measure traffic volume on the road while the speed gun (model Stalker Lidar RS-232) was shot at different types of vehicles several times in order to compute the average speed of each type of vehicles.

\subsection{Data Analysis}

Statistical analysis was performed using SPSS for Windows (version 17.0, SPSS Inc.). One-Way Analysis of Variance (ANOVA) was used to determine any significant differences between two or more noise levels measured at sites of the study. Independent samples t-test was used to compare independent groups (noise levels at two different studied sites and areas). In the present study, $p$ values of less than $5 \%(p<0.005)$ were considered as statistically significant.

\section{Results and Discussion}

Based on the guidelines for environmental noise limits and control by the Department of Environment (DOE, 2007), the maximum permissible sound level (LAeq) for medium density areas during daytime from 7.00 am to $10.00 \mathrm{pm}$ is 55 $\mathrm{dB}(\mathrm{A})$ while at night time from $10.00 \mathrm{pm}$ to $7.00 \mathrm{am}$ is $45 \mathrm{~dB}(\mathrm{~A})$. For high density area, the permissible limits are $60 \mathrm{~dB}(\mathrm{~A})$ for daytime and $55 \mathrm{~dB}(\mathrm{~A})$ for night time while for low density area the permissible limits are $50 \mathrm{~dB}(\mathrm{~A})$ for daytime and $40 \mathrm{~dB}(\mathrm{~A})$ for night time.

In this study, road traffic analysis was carried out with speed of vehicles and traffic composition. The increase in the vehicles since last 10 years has put lot of pressure on the existing roads and ultimately resulting in noise pollution. 
As this case is increasingly becoming an issue, this study was carried out to find out which of the following studied site were affected.

Traffic composition data were collected according to vehicles type and was monitored manually in every 15 minutes for three intervals which are in the morning, evening and night. The results of average speed in Nibong Tebal and Juru areas during weekdays and weekends are presented in Fig. 3 and Fig. 4.

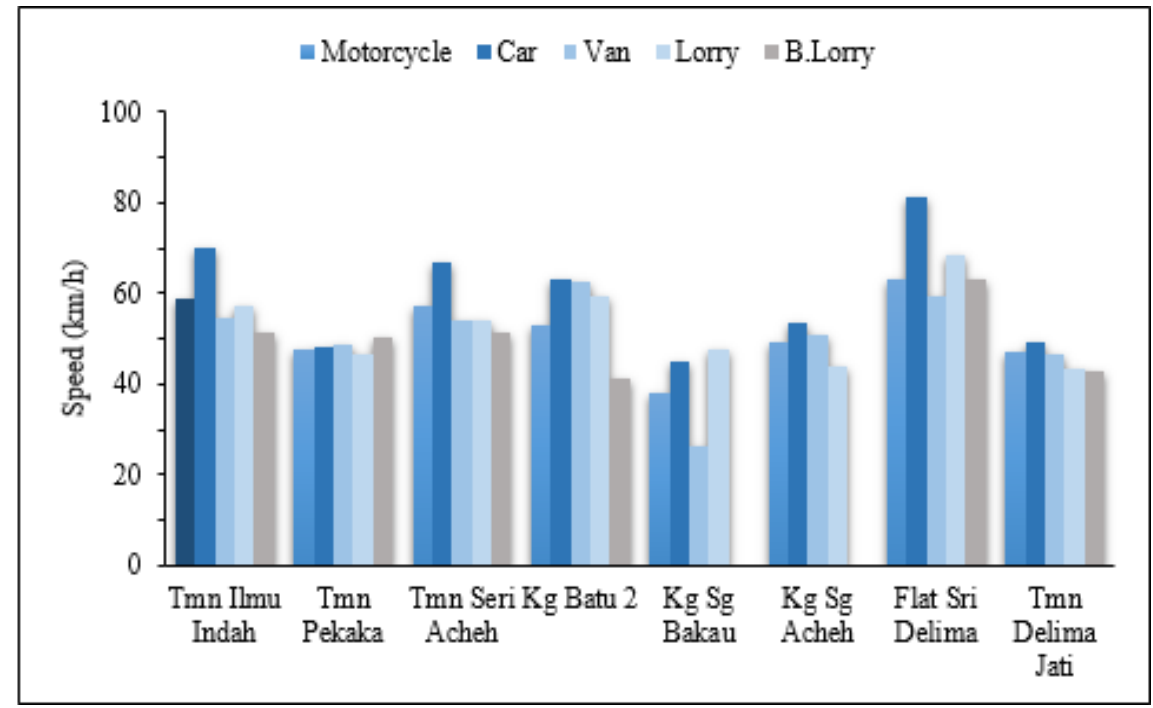

Fig. 3 - Average speed in Nibong Tebal and Juru during weekdays

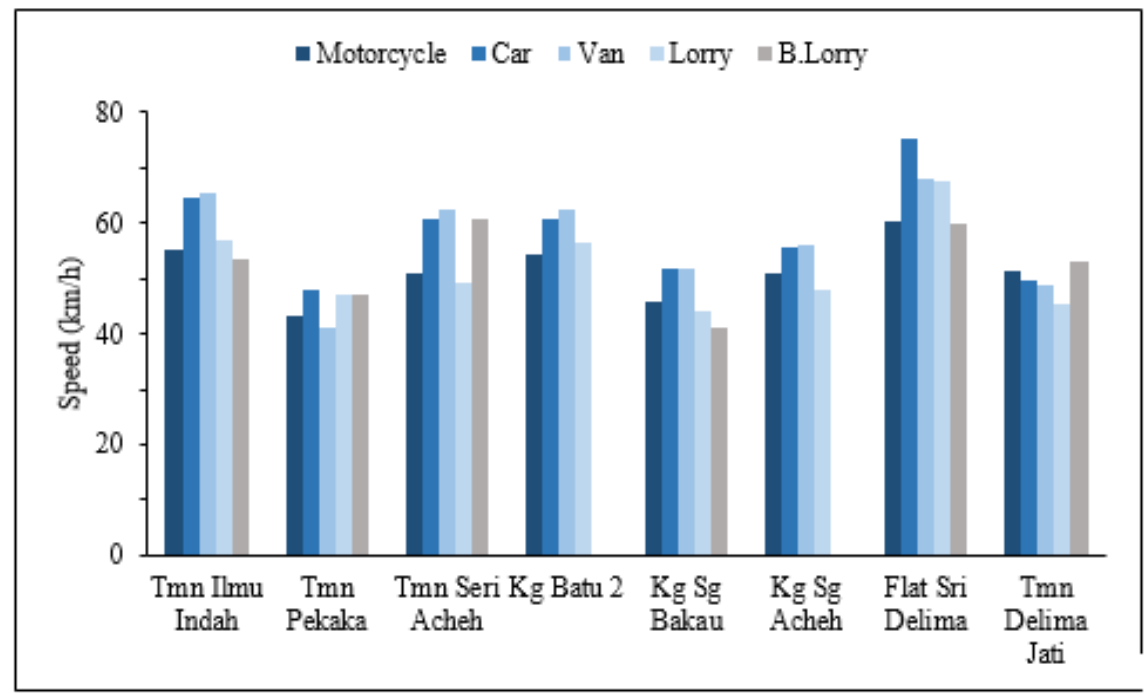

Fig. 4 - Average speed in Nibong Tebal and Juru during weekends

From Fig. 3 and Fig. 4, the results represent average speed at the eight studied sites. From Fig. 3, it shows that Flat Sri Delima recorded the highest average speed of car during weekdays compared to other studied sites with $81.24 \mathrm{~km} / \mathrm{h}$. In addition, percentage of cars is the highest traffic composition for every studied site except for Taman Pekaka and Kampung Sungai Bakau. A comparison between Nibong Tebal studied sites and Juru studied sites shows that there is a different pattern in percentage of traffic composition. This is because in Juru, the measurement was taken near to the busiest road and highway that headed to industrial area. A study by Lokhande et al. [20] stated that many highways are going through the residential and commercial areas due to limited availability of land resources, which increase the vehicular noise in urban areas leading to environmental issues. In addition, the high noise levels is contributed by engine of the vehicles. Motor vehicle noise, including noise from automobiles, motorcycles, buses, and trains, is a result of vehicle traction systems including the engine that interface of the wheel which is important at high speeds [21].

Table 3 shows the number of vehicles in Nibong Tebal and Juru during weekdays. In Nibong Tebal area, Taman Pekaka recorded the highest percentage in number of cars with 73.2\% (473) while Kampung Sungai Acheh recorded 
the lowest percentage in number of cars with $38.7 \%$ (48). While in Juru, the highest percentage of cars with $68.9 \%$ (201) and the lowest percentage was van with 2.7\% (8), both at Flat Sri Delima. Table 4 shows number of vehicles in Nibong Tebal and Juru during weekends. The comparison on weekends shows that the results in Nibong Tebal changed in percentage. Taman Sri Acheh recorded as the highest percentage in car vehicle with 76.7\% (530) and the least number of vehicles in Nibong Tebal were Kampung Sungai Acheh and Kampung Batu 2 with 0\% as no heavy lorries passed by the sites as the sites are low density population residential areas (village). In Juru, similar results were obtained as weekdays which car was still the highest vehicles on the road at Flat Sri Delima with 79.0\% (241). The least vehicle was van at Taman Delima Jati with $2.5 \%$ (7). Traffic increases on the road dramatically on weekends when many people living in the city use the road. The same finding was obtained in this study as the number of vehicles on the road was higher on weekends compared to weekdays.

Table 3 - Number of vehicles in Nibong Tebal and Juru during weekdays

\begin{tabular}{ccccccccc}
\hline $\begin{array}{c}\text { Class of } \\
\text { vehicles }\end{array}$ & $\begin{array}{c}\text { Tmn } \\
\text { Ilmu } \\
\text { Indah }\end{array}$ & $\begin{array}{c}\text { Tmn } \\
\text { Pekaka }\end{array}$ & $\begin{array}{c}\text { Tmn } \\
\text { Seri } \\
\text { Acheh }\end{array}$ & $\begin{array}{c}\text { Kg } \\
\text { Batu 2 }\end{array}$ & $\begin{array}{c}\text { Kg Sg } \\
\text { Bakau }\end{array}$ & $\begin{array}{c}\text { Kg Sg } \\
\text { Acheh }\end{array}$ & $\begin{array}{c}\text { Tmn } \\
\text { Delima } \\
\text { Jati }\end{array}$ & $\begin{array}{c}\text { Flat Sri } \\
\text { Delima }\end{array}$ \\
\hline Cars & 220 & 473 & 232 & 169 & 61 & 48 & 118 & 201 \\
\hline Vans & 7 & 26 & 22 & 9 & 6 & 2 & 7 & 8 \\
\hline Motorcycles & 87 & 115 & 72 & 122 & 79 & 68 & 29 & 22 \\
\hline $\begin{array}{c}\text { Small } \\
\text { lorries }\end{array}$ & 12 & 25 & 58 & 16 & 6 & 6 & 29 & 28 \\
\hline $\begin{array}{c}\text { Heavy } \\
\text { vehicles }\end{array}$ & 7 & 7 & 29 & 1 & 0 & 0 & 10 & 33 \\
\hline
\end{tabular}

Table 4 - Number of vehicles in Nibong Tebal and Juru during weekends

\begin{tabular}{ccccccccc}
\hline $\begin{array}{c}\text { Class of } \\
\text { vehicles }\end{array}$ & $\begin{array}{c}\text { Tmn } \\
\text { Imu } \\
\text { Indah }\end{array}$ & $\begin{array}{c}\text { Tmn } \\
\text { Pekaka }\end{array}$ & $\begin{array}{c}\text { Tmn } \\
\text { Seri } \\
\text { Acheh }\end{array}$ & $\begin{array}{c}\text { Kg } \\
\text { Batu 2 }\end{array}$ & $\begin{array}{c}\text { Kg Sg } \\
\text { Bakau }\end{array}$ & $\begin{array}{c}\text { Kg Sg } \\
\text { Acheh }\end{array}$ & $\begin{array}{c}\text { Tmn } \\
\text { Delima } \\
\text { Jati }\end{array}$ & $\begin{array}{c}\text { Flat Sri } \\
\text { Delima }\end{array}$ \\
\hline Cars & 246 & 586 & 530 & 233 & 192 & 126 & 191 & 241 \\
\hline Vans & 35 & 17 & 19 & 12 & 10 & 8 & 7 & 8 \\
\hline Motorcycles & 87 & 285 & 93 & 120 & 168 & 97 & 53 & 21 \\
\hline $\begin{array}{c}\text { Small } \\
\text { lorries }\end{array}$ & 7 & 11 & 30 & 4 & 4 & 8 & 18 & 18 \\
\hline $\begin{array}{c}\text { Heavy } \\
\text { vehicles }\end{array}$ & 4 & 8 & 19 & 0 & 1 & 0 & 8 & 16 \\
\hline
\end{tabular}

Fig. 5 and Fig. 6 illustrate the noise levels in Nibong Tebal and Juru during weekdays and weekends. All noise levels at all locations exceeded the noise limits stated for low, medium and high density population of residential areas as stated in the guideline of Department of Environment (DOE) Malaysia. Fig. 5 represents the noise levels in Nibong Tebal during weekdays and weekends. The results clearly indicate that all the studied sites experienced very high noise levels all the time including night time. These results reveal that the people live and trade in this Nibong Tebal studied sites are exposed to high noise level that exceed the permissible limit. According to the results, it shows that the highest noise level mostly recorded during evening time with the range of noise levels $56.3 \mathrm{~dB}(\mathrm{~A})$ to $67.8 \mathrm{~dB}(\mathrm{~A})$. The noise level was higher during peak hours, particularly during evenings when there were increased traffic volumes and a higher percentage of heavy vehicles. This finding is in line with a study of road traffic noise levels in Bukit Mertajam, Penang by Aziz et al. [22] where the increasing number of traffic volume and high percentage of heavy vehicles contributed to the high noise levels recorded.

From the results in Fig. 6, Flat Sri Delima shows that residents in that area exposed towards higher noise pollution compared to Taman Delima Jati during weekdays (on both daytime and night time) because during day time the highest noise level was $72.11 \mathrm{~dB}(\mathrm{~A})$ and in night time was $68.20 \mathrm{~dB}(\mathrm{~A})$, respectively. However, during weekends, Taman Delima Jati residents were exposed to higher noise level with $67.71 \mathrm{~dB}(\mathrm{~A})$ in the morning, $68.43 \mathrm{~dB}(\mathrm{~A})$ in the evening and $67.38 \mathrm{~dB}(\mathrm{~A})$ at night. Taman Delima Jati residents received the highest noise levels during weekday because the road near the residential area located in industrial area.

The comparison between Juru and Nibong Tebal shows that residents in Juru are exposed to higher noise level compared to residents in Nibong Tebal. Nibong Tebal recoded the lowest reading in the noise levels may due to the residential areas where the numbers of the resident are less compared to the Juru. Hence, the noise levels are low in Nibong Tebal areas. The residents also contribute to the noise levels on the nearby roads due to their trips generation on the road, especially during going to work and coming back from work trip generation. 


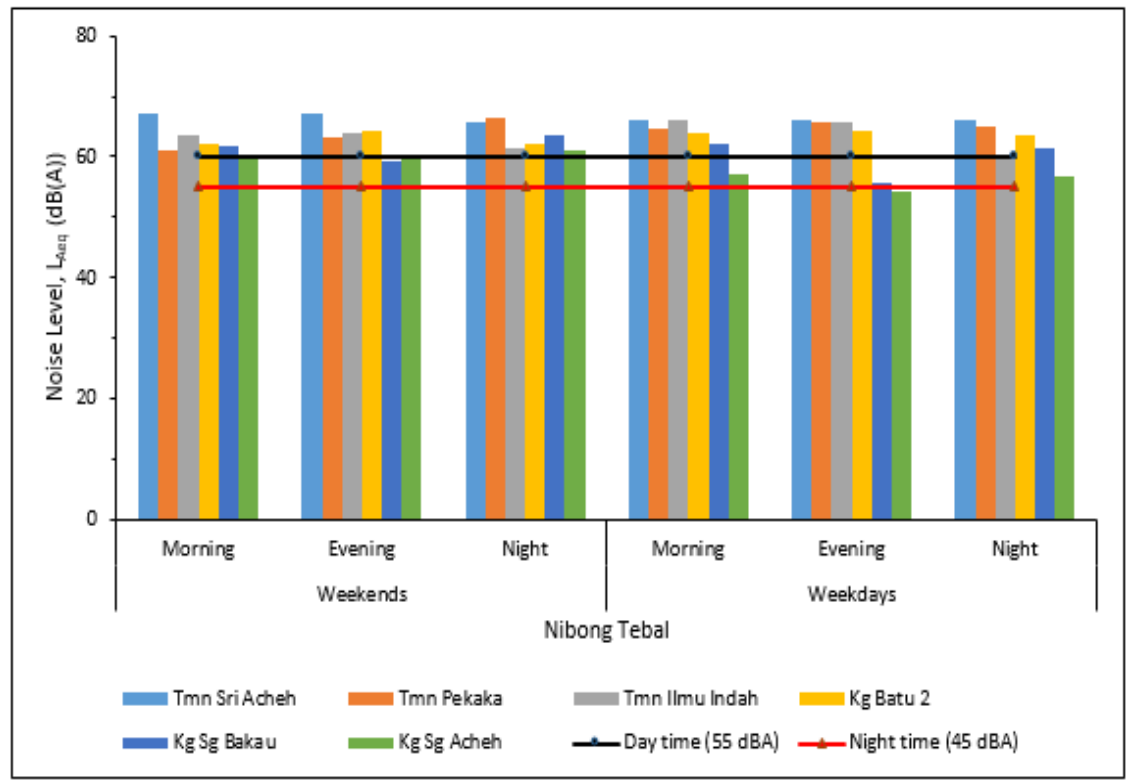

Fig. 5 - Noise Level in Nibong Tebal during weekdays and weekends

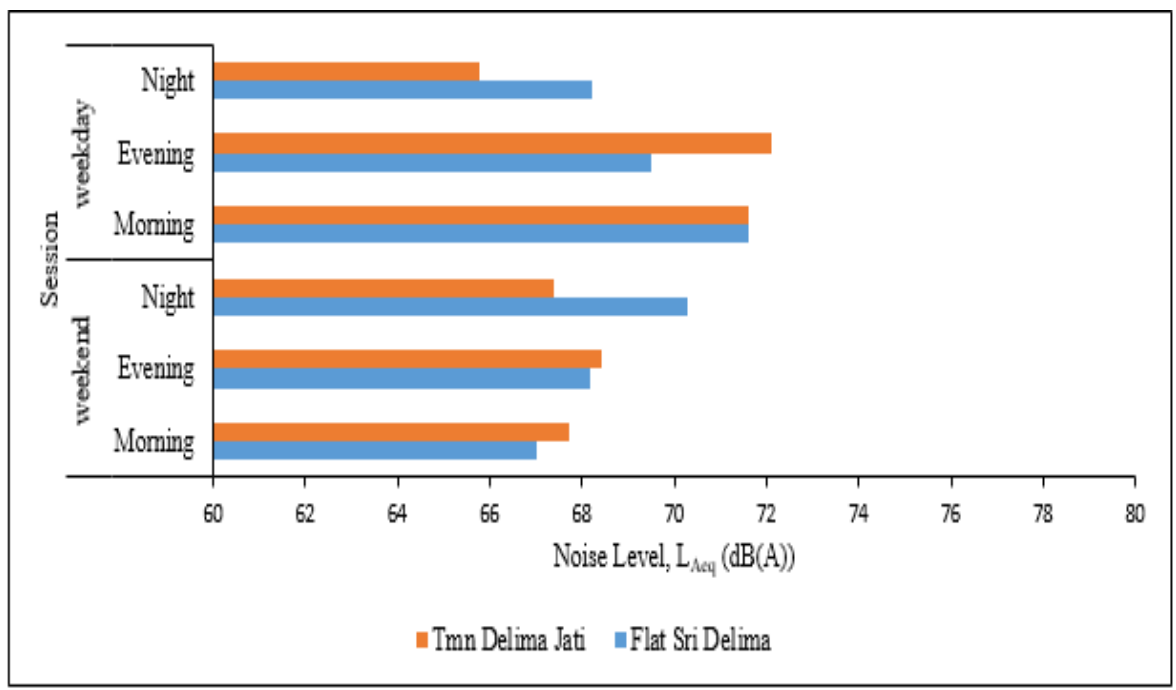

Fig. 6 - Noise Level in Juru during weekdays and weekends

Temporal variation of noise levels was examined at each studied site using independent samples t-test to determine whether the mean samples of noise levels obtained in the measurement period differ from different studied sites. A quick check of the box plots shown in Fig. 7 and Fig. 8 indicate that the mean at Taman is much higher than the mean of morning (represent daytime) and night noise levels at kampung in Nibong Tebal areas. The null hypothesis states that, there are no difference in the mean samples of LAeq in daytime and night time at taman (medium density residential areas) and kampung (low density residential areas). The independent samples t-test was run to determine if there were difference of noise levels of road traffic in medium density residential areas and low density population residential areas. The test confirmed that there was significant difference in mean of noise levels between medium density residential areas $(\mathrm{M}=64.82, \mathrm{SD}=3.10) ; \mathrm{t}(156.221)=7 ., \mathrm{p}<0.001$. The mean of noise levels at medium density residential areas was 4.61 higher than low density population residential areas noise levels. Levene's test indicated unequal variances ( $\mathrm{f}=15.817, \mathrm{p}<0.001$ ), so degree of freedom was adjusted from 190 to 156.221 and low density population residential areas. The results obtained from independent samples t-test revealed that the null hypothesis was rejected and research hypothesis was supported. This is because the corresponding p-value of 0.000 (medium density population residential areas) and 0.01 (low density population residential areas), respectively were very much smaller than alpha of 0.05 . There is a significant difference between noise levels in medium density and low density population residential areas. Apart from that, there were outliers labelled with numbers outside (the number of data arranged in the 
SPSS cell) of the box plots in Fig. 7 and Fig. 8. Outliers is an observation that is numerically distant from the rest of the data.

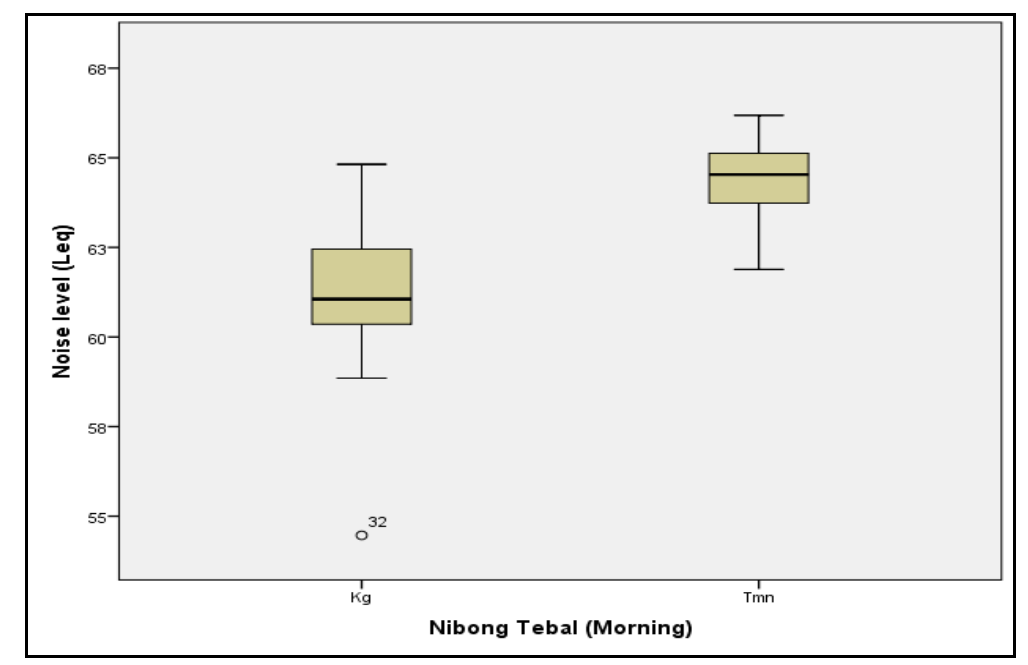

Fig. 7 - Comparison of Noise Level in Nibong Tebal at morning time

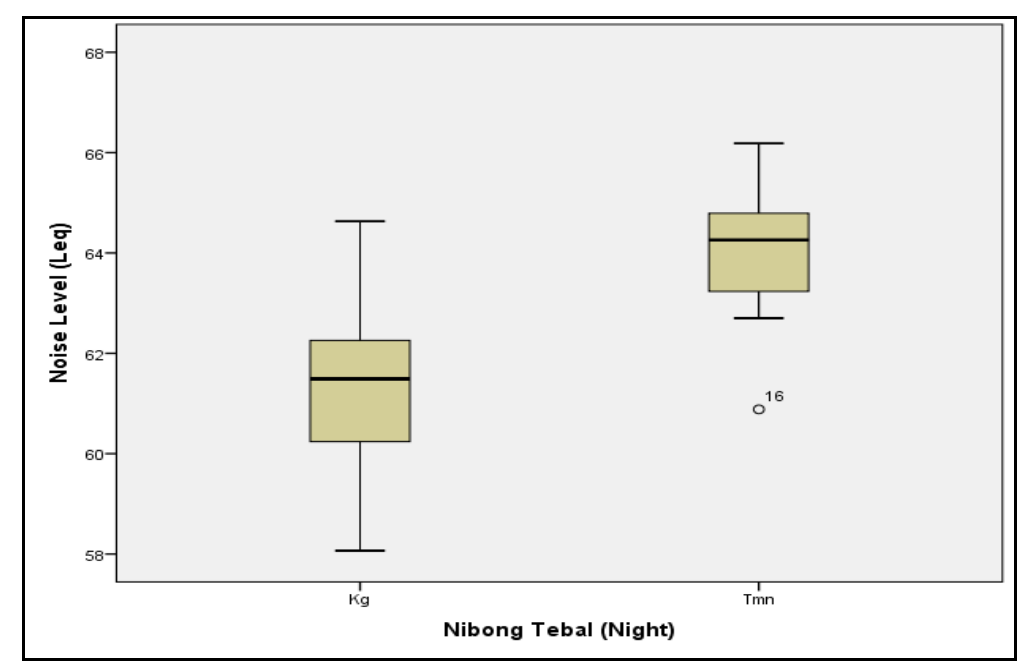

Fig. 8 - Comparison of Noise Level in Nibong Tebal at night time

There is also a quick check of the box plot as shown in Fig. 9. The result indicates that mean of noise levels in Juru is much higher compared to the noise level in Nibong Tebal. The null hypothesis states that, there are no difference in the mean samples of noise level (LAeq) in Juru and Nibong Tebal. The results obtained from independent samples ttest revealed and the decision is that null hypothesis was rejected and research hypothesis was supported, this is because the corresponding p-value 0.000 was very much smaller than alpha of 0.05 .

A one-way ANOVA was conducted to determine the significant differences of noise levels between medium density residential areas in Nibong Tebal, Penang. The noise levels of road traffic at three studied sites in medium density residential areas were normally distributed, as assessed by Shapiro-Wilks test ( $\mathrm{p}>0.05)$. There is homogeneity of variances as assessed by Levene's Test for Homogeneity of Variances $(p=0.363)$. There was statistically significant difference between noise levels at three medium density residential areas as determined by one-way ANOVA $(\mathrm{F}(2,93)=$ 16.236, $\mathrm{p}=0.000)$. A Tukey Post Hoc Test revealed that noise levels at Taman Pekaka $(\mathrm{M}=64.67, \mathrm{SD}=2.35)$ and Taman Ilmu Indah $(\mathrm{M}=62.98, \mathrm{SD}=2.63)$ are statistically significantly lower compared to Taman Sri Acheh $(\mathrm{M}=66.82, \mathrm{SD}=$ 3.07). This might be because Taman Sri Acheh is located next to a busy Federal Route 1 road compared to the other two medium density residential areas. Fig. 10 illustrates the boxplots of LAeq for all medium density residential areas. 


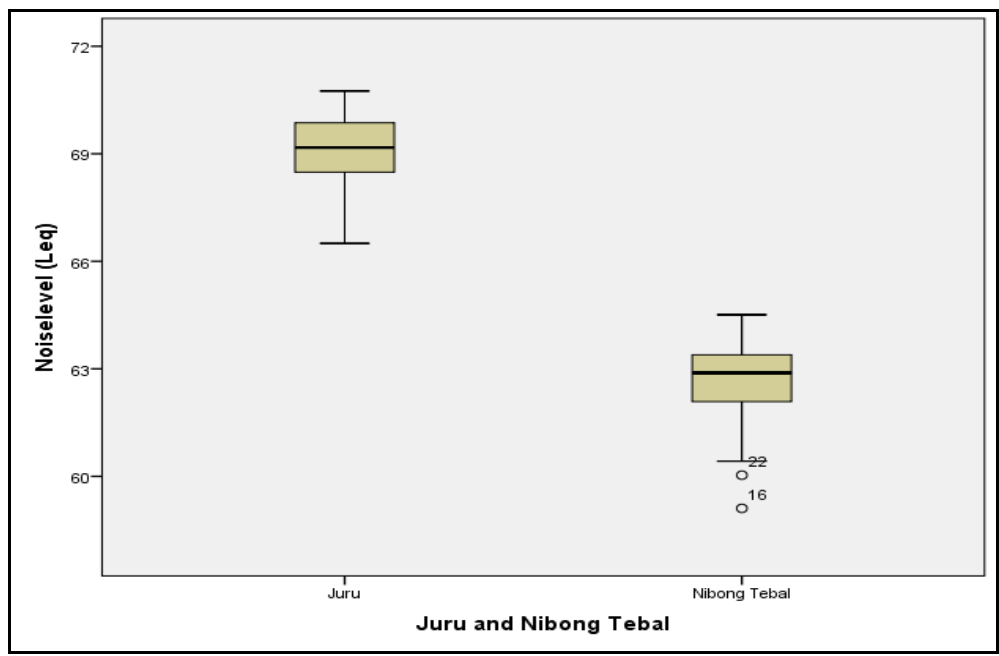

Fig. 9 - Comparison of Noise Level in Juru and Nibong Tebal areas

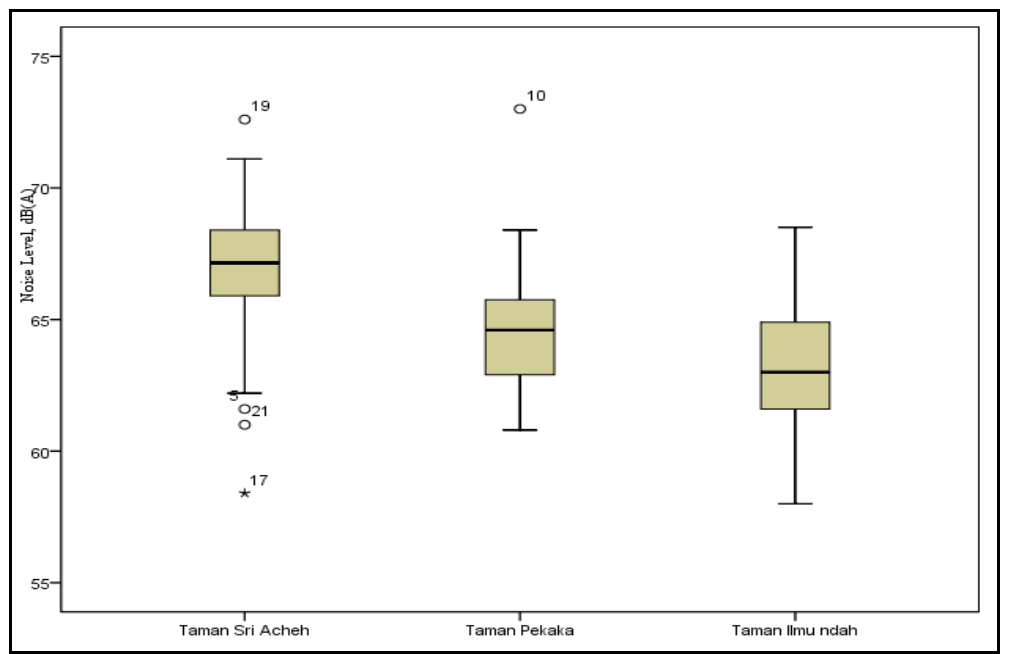

Fig. 10 - Comparison of noise levels between medium density residential areas

Spatial variation of noise levels was investigated at each studied site and area to identify whether the obtained mean of the noise levels differs from each other. Fig. 11 indicates that the mean of Flat Sri Delima (FSD) is slightly lower than Taman Delima Jati (TDJ) during weekdays, while in Fig. 12, the mean of Flat Sri Delima (FSD) is slightly larger than Taman Delima Jati (TDJ) during weekends. Fig. 13 and Fig. 14 indicate that the mean of low density residential areas is smaller than medium density residential areas in Nibong Tebal for both weekends and weekdays. In addition, for Fig. 15 the mean of noise level in Juru is larger than Nibong Tebal. In a summary, the relationship of LAeq at FSD and TDJ null hypothesis was supported. This is because the corresponding p-value 0.906 and 1.411 was larger than the alpha of $0.05(\mathrm{p}<0.05)$ and the relationship of LAeq at medium density residential areas and low density residential areas give that null hypothesis was not supported. This is because the corresponding $\mathrm{p}$-value 0.000 was smaller than the alpha of $0.05(\mathrm{p}<0.05)$. From a previous study [23], the lowest value is 1.0, which represents the common underlying road traffic noise loudness scale that was used and the null hypothesis assuming the validity of the model may not be rejected. There were outliers labelled with numbers outside (the number of data arranged in the SPSS cell) of the box plots in Fig. 10 and Fig. 12 to Fig. 15, which mean observation that is numerically distant from the rest of the data. 


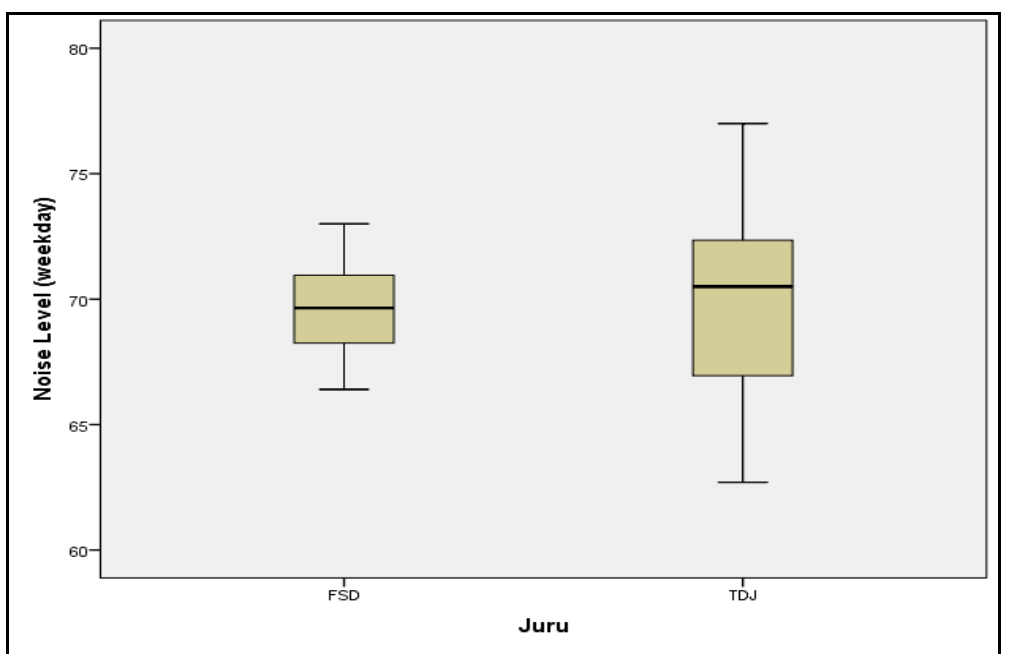

Fig. 11 - The boxplot of mean sample of Flat Sri Delima (FSD) and Taman Delima Jati (TDJ) in Juru during weekdays

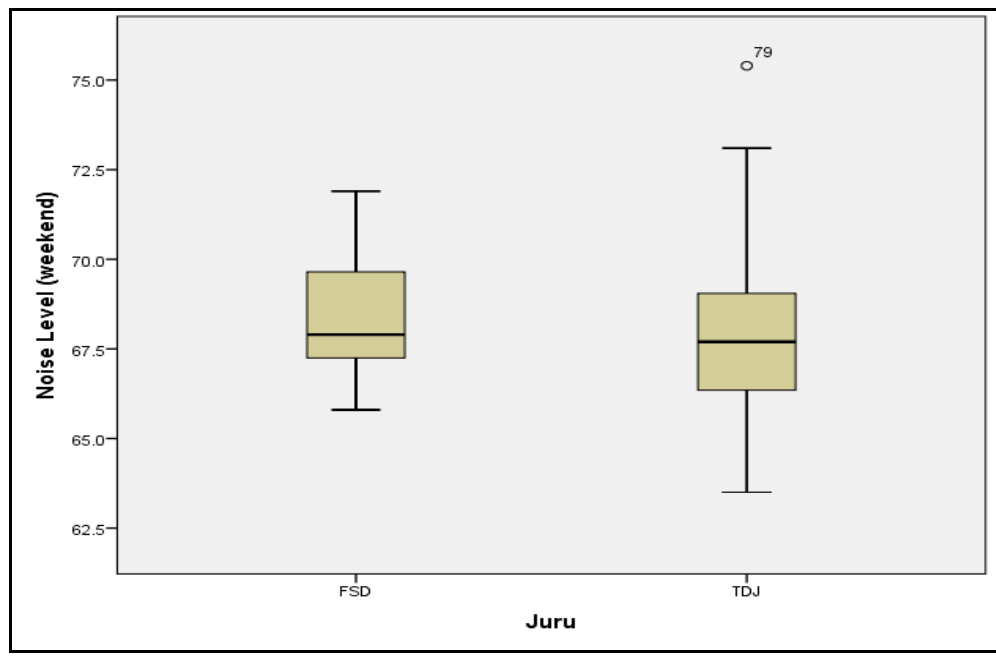

Fig. 12 - The boxplot of mean sample of Flat Sri Delima (FSD) and Taman Delima Jati (TDJ) in Juru during weekends

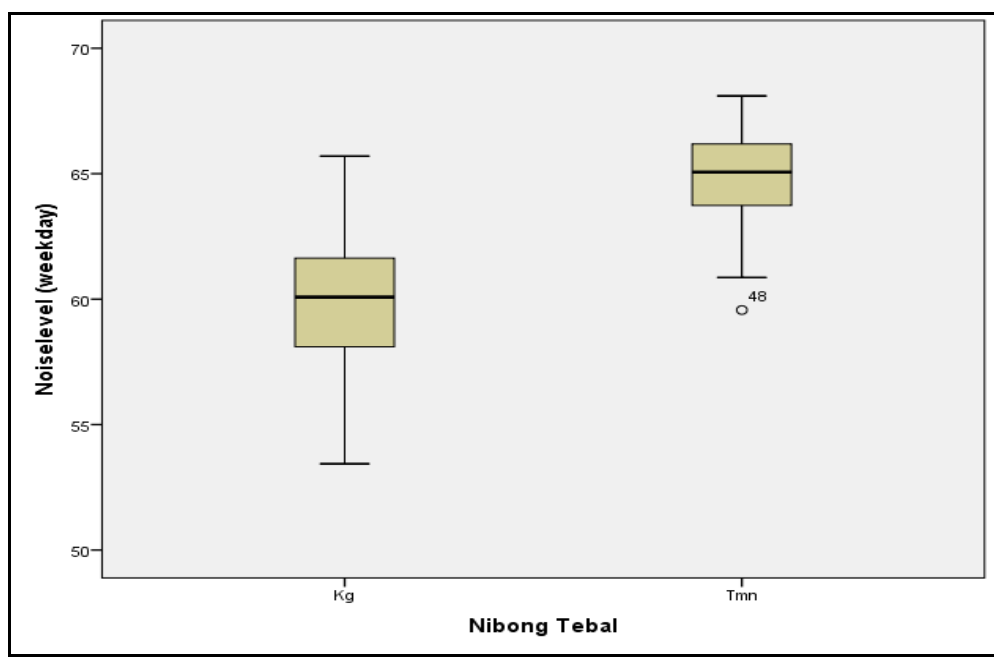

Fig. 13 - The boxplot of mean sample of Kampung (Kg) and Taman (Tmn) in Nibong Tebal during weekdays 


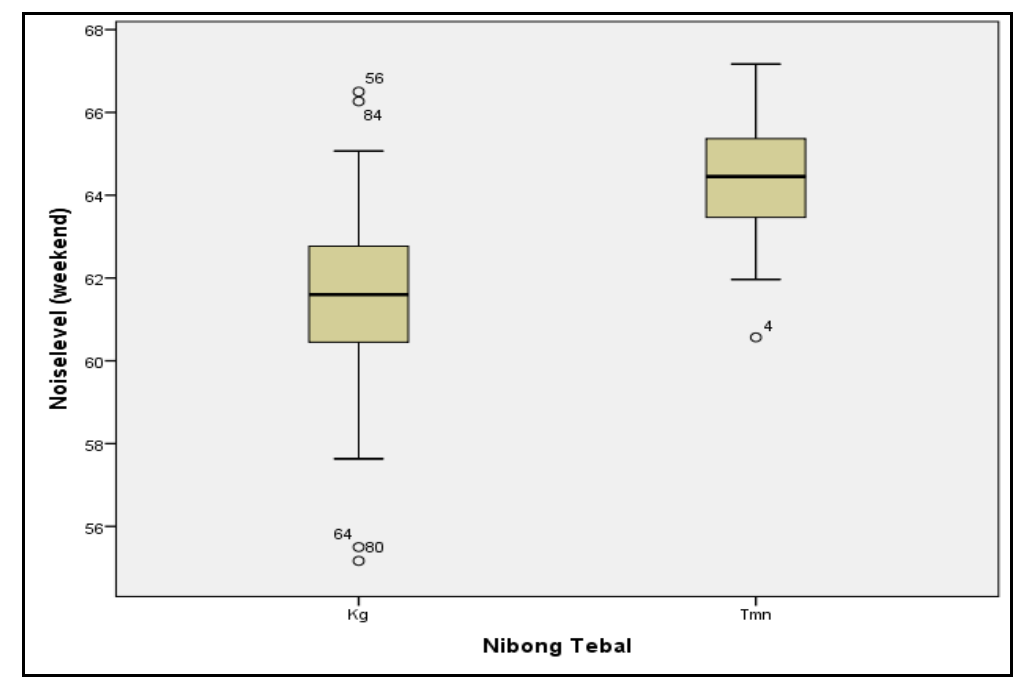

Fig. 14 - The boxplot of mean sample of Kampung (Kg) and Taman (Tmn) in Nibong Tebal during weekends

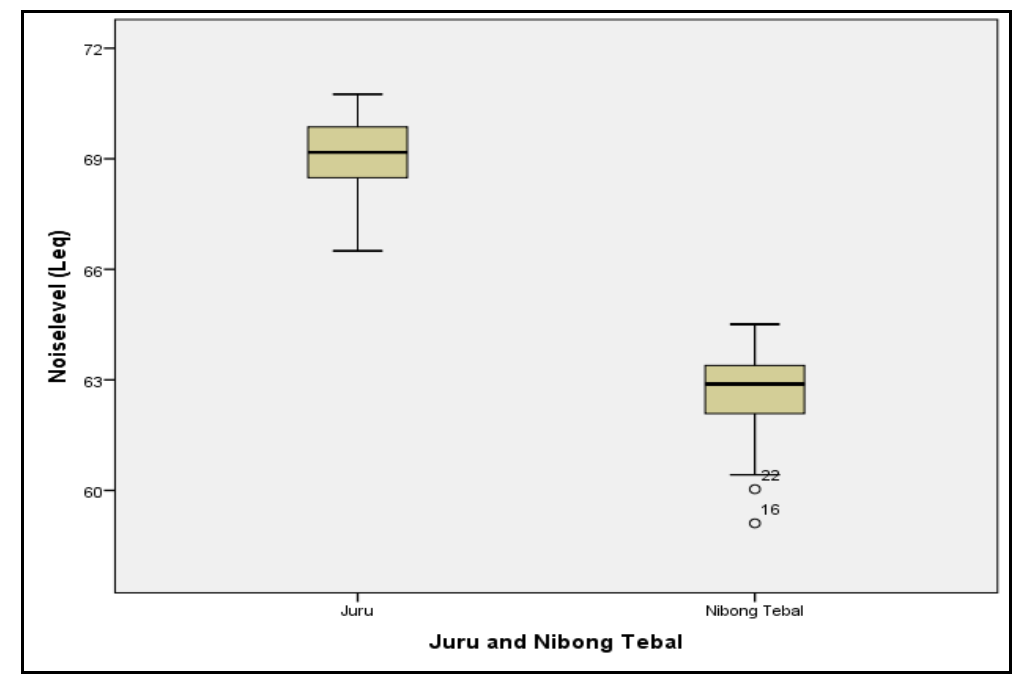

Fig. 15 - The boxplot of mean sample of Juru and Nibong Tebal

\section{Summary}

From this study, it can be concluded that the vehicle composition of heavy vehicles such as lorries, buses and containers contribute to the noise levels. A comparison between Nibong Tebal studied sites and Juru studied sites shows that there is a different pattern in percentage of traffic composition. This is because in Juru, the measurement was taken near to the busiest road and highway that headed to industrial area. Furthermore, all noise levels were very high all the time including non- peak hour period at all studied sites and the noise levels exceeded the noise limits stated for low, medium and high density population of residential areas as stated in the guideline of Department of Environment (DOE) Malaysia. According to the results, it shows that the highest noise level mostly recorded during evening time. The noise level was higher during peak hours, particularly during evenings when there were increased traffic volumes and a higher percentage of heavy vehicles. The highest LAeq was recorded in Juru Flat Sri Delima (Juru) at night time with $70.26 \mathrm{~dB}(\mathrm{~A})$. Nibong Tebal recoded the lowest reading in the noise levels may be due to the residential areas, where the numbers of the resident are less compared to the Juru. Hence, the noise levels are low in Nibong Tebal areas. The residents also contribute to the noise levels on the nearby roads due to their trips generation on the road, especially during go to work and come back from work trip generation.

\section{Acknowledgement}

The authors would like to thank School of Civil Engineering, Universiti Sains Malaysia for the support of this project. Thanks also to Universiti Sains Malaysia for providing financial support under the Short Term Grant (304/PAWAM/6315066) to carry out this study. 


\section{References}

[1] Chew, Y. R. and Wu, B. S. (2016). A soundscape approach to analyze traffic noise in the city of Taipei, Taiwan. Computers, Environment and Urban Systems, 59, 78-85.

[2] Pandya, G. H. and Dharmadhikari, D. M. (2002). A Comprehensive investigation of noise exposure in and around an integrated iron and steel works. AIHA Journal, 63, 172-177.

[3] Hassan S., Taha H. M., Sidek D. and Ismail C. (2013). Field survey on road traffic noise, evaluation of hearing loss and associated risk factors in the community of Kota Bharu, Malaysia. Pakistan Journal of Otolaryngology, 28, 3-6.

[4] Okokon E. O., Turunen A. W., Ung-Lanki S., Vartiainen, A., Tiittanen P. and Lanki T., (2015). Road-traffic noise: Annoyance, risk perception, and noise sensitivity in the finnish adult population. International Journal of Environmental Respiratory and Public Health, 12(6), 5712-5734.

[5] Okokona E. O., Tarja Y. T., Turunena, A.W., Tiittanena, P., Juutilainenb, J., Lankia, T. (2018). Traffic noise, noise annoyance and psychotropic medication use. Environment International, 119, 287-294.

[6] World Health Organization (2000). Guidelines for community noise. Geneva, pp 1-141.

[7] World Health Organization (2009). Night noise guidelines for Europe. Copenhagen, pp 1-162.

[8] Ramírez, A. and Domínguez, E. (2013). Modeling urban traffic noise with stochastic and deterministic traffic models. Applied Acoustics, 74(4), 614-621.

[9] Halim, H., Abdullah, R., Nor, M. J. M., Aziz, H. A. and Rahman, N.A. (2017). Assessment of road traffic noise indices in urban residential areas of Klang Valley, Malaysia. AIP Conference Proceedings, 1892, pp 060007.

[10] Bavani, N., Yap, X. W. and Ramdzani, A. (2010). Effect of traffic noise on sleep: A case study in Serdang Raya, Selangor, Malaysia. Environment Asia, 3, 149-155.

[11] Elfaig, A. M. D. (2000). Noise pollution and community perception in mixed residential areas of Kuala Lumpur. Proceeding of the 6th Congress on Environmental Health, OSLO.

[12] Elfaig, A. M. D., Mohd Zohadie, M. D., Rahman, M.M and Abdullah, R. (2000). Community noise pollution: Perception and reality at the school compounds in Kuala Lumpur, Malaysia. Suranaree Journal of Science and Technology, 7, 161-167.

[13] Organisation for Economic Co-operation and Development (2011). Review of higher education in regional and city development, State of Penang, Malaysia. Retrieved on August 25, 2018 from www.oecd.org/education/imhe/47506877.pdf

[14] Roswall, N., Raaschou-Nielsen, O., Ketzel, M. Gammelmark, A., Overvad, K., Olsen, A. and Sørensen, M. (2017). Long-term residential road traffic noise and NO2 exposure in relation to risk of incident myocardial infarction-a Danish cohort study. Environmental Research, 156, 80-86.

[15] Fecht, D., Hansell, A.L., Morley, D., Dajnak, D., Vienneau, D., Beevers, S., Gulliver, J. (2016). Spatial and temporal associations of road traffic noise and air pollution in London: Implications for epidemiological studies. Environmental International, 88, 235-242.

[16] Tenailleau, Q. M., Bernard, N., Pujol, S., Parmentier, A. L., Boilleaut, M., Houot, H., Mauny, F. (2016). Do outdoor environmental noise and atmospheric NO2 levels spatially overlap in urban areas? Environmental Pollution, 214, 767-775.

[17] Department of Environment (2007). The planning guidelines for environmental noise limits and control. Putrajaya: Department of Environment Malaysia.

[18] Jagniatinskis, A., Fiks, B., Zaporozhets, O. and Mickaitis, M. (2017). Annual assessment of noise generated by road traffic using measurements. Procedia Engineering, 187, 614-619.

[19] PLUS (2018). Vehicles classess. Retrieved on August 28, 2018 from http://www.plus.com.my/index.php?option $=$ com_content $\&$ view $=$ article $\& i d=82 \& I t e m i d=118 \& l a n g=e n$.

[20] Lokhande, S. K., Pathak, S. S., Kokate, P. K. and Bodhe, G. L. (2016). Evaluation and forecasting of highway traffic noise in the City of Nagpur, India. International Journal of Earth Sciences and Engineering, 9(4), 15291535.

[21] Bhatiar R. (2014). Noise pollution: Managing the challenge of urban sounds. Retrieved on August 28, 2018 from https://earthjournalism.net/@ @ search?Subject\%3Alist=Noise\%20Pollution

[22] Aziz, S. Q., Lulusi, S., Asaari, F. A. H., Ramli. N. A., Aziz, H. A., Mojiri, A., Umar, M. (2012). Assessment of traffic noise pollution in Bukit Mertajam, Malaysia and Erbil City, Iraq. Caspian Journal of Applied Sciences Research, 1(3), 1-11.

[23] Coensel, B. D., Vanwetswinkel, S. and Botteldooren, D. (2011). Effects of natural sounds on the perception of road traffic noise. The Journal of the Acoustical Society of America, 129(4), 148-153. 